\title{
J. S. MILL AND ROBERT VEATCH'S CRITIQUE OF UTILITARIANISM
}

\author{
Rem B. Edwards \\ University of Tennessee
}

Modern bioethics is clearly dominated by deontologists who believe that we have some way of identifying morally correct and incorrect acts or rules besides taking account of their consequences. Robert $M$. Veatch is probably the most outspoken of those numerous modern medical ethicists who agree in rejecting all forms of teleological, utilitarian or consequentialists ethical theories. This paper will examine his critique of utilitarianism and show that the utilitarianism of John Stuart Mill is either not touched at all by his critique or can be defended against it. I am convinced that the dominant deontological majority is mistaken and that a utilitarian theory of moral action very much like Mill's is precisely what is needed by modern medical ethics and by those medical practitioners who are resolved to practice medicine in a reasonable and morally acceptable manner.

\section{Part 1. Veatch on Mill's Basic Moral Principle}

I would like to point out initially that Veatch's critique of Mill's utilitarianism has not kept up with or taken account of some of the most recent scholarly work that has been done on Mill. In his recent $A$ Theory of Medical Ethics, Veatch classifies Mill with Bentham as one who adopts as his "basic moral principle" what turns out to be the fundamental action-guiding norm of act utilitarianism, i.e. that we are morally obligated to perform that act which will maximize good consequences for those affected. Veatch states what he often calls both "the utilitarian principle"! and "the principle of beneficence," as follows, clearly including Mill:

... one might be tempted to say-along with Bentham, Mill, and the utilitarians-that the society should adopt as its basic moral principle the one which states that the right course is that which will produce at least as much net benefit as alternative courses . . . It seems to require that for every choice in a human life, one is obligated to choose the one course that would maximize net aggregate total consequences. ${ }^{3}$

Many contemporary medical ethicists, including Veatch, who reject utilitarianism make the unwarranted assumptions that all utilitarians are alike in accepting the duty to maximize goodness as the most

Dr. Rem B. Edwards is Professor of Philosophy at the University of Tennessee. He is the author of five books, including Pleasures and Pains, A Theory of Qualitative Hedonism, Cornell University Press, 1979, and Psychiatry and Ethics, Prometheus Books, 1982. 
fundamental moral principle and in assuming that all utilitarians are committed to applying their fundamental moral principles in exactly the same way. Wholesale condemnations of utilitarianism fail to recognize that there are many forms of and applications of utilitarianism. Mill himself insisted that utilitarians were united in their "recognition of utility as a standard, not any particular way of applying it." 4 There are some very important differences in the way in which the Principle of Utility gets formulated and in the way in which it enters into utilitarian theories of moral obligation.

Mill's own "basic moral principle" was not identical with the Principle of Utility. Contrary to Veatch's assumption, Mill did not subscribe to a maximizing utilitarianism like modern act or rule utilitarianism. Mill did not believe that we have a moral obligation to maximize goodness or to be benevolent in Veatch's sense, though Veatch no doubt is in accord with the standard textbook stereotype of Mill which has never been based on a careful reading of Mill. However, a number of important studies of Mill have been published in the last decade or so by such scholars as D. G. Brown, David Lyons and Gerald F. Gaus which show quite conclusively that on the whole Mill was not a maximizing moral utilitarian at all. 5 The mistaken belief that he adopted the maximization of goodness as his basic moral principle has been based primarily on the assumption that Mill's basic moral principle was identical with the Principle of Utility. However, Mill actually treated the Principle of Utility as the first principle of his general axiology or "Teleology," or "the Art of Life," as he called it in his Logic. ${ }^{6}$ As such it was the "source," "foundation," "criterion" or "test" of morals, but he repeatedly insisted that many special considerations had to be introduced in order to derive a theory of morals from the basic axiom of the Art of Life.

To make a long story short, Mill's Principle of Utility, the first principle of the Art of Life, is best paraphrased as: Actions, virtues, rules and other instrumental goods are desirable (and in that sense correct or right) to the extent that they tend to promote the happiness of the greatest number of persons or sentient beings; and they are undesirable to the extent that they tend to promote the reverse of happiness. By contrast, Mill's fundamental moral principle is best paraphrased as: We are morally obligated only to abstain from inflicting harm, to actively prevent harm, to actively provide for other persons or sentient beings certain minimal essentials of any sort of well being whatsoever, and beyond that to contribute a decent minimum to charity. Among the minimal essentials for persons are such things as life, liberty, security, individuality and self-development, food and shelter, basic health care, basic education, equality or opportunity to pursue happiness, etc. Our rights correlate with these minimal essential goods, as will be explained later. The majority of moral duties, i.e. liberty-restricting duties to be compelled by society, which Mill 
recognized were clearly negative duties to avoid and prevent harm. This comes out repeatedly in all the works in which Mill discussed the topic of moral obligation. To give one conspicuous example: "The sole end for which mankind are warranted, individually or collectively, in interfering with the liberty of action of any of their number, is selfprotection. That the only purpose for which power can be rightfully exercised over any member of a civilized community, against his will, is to prevent harm to others." In his earlier Death, Dying and the Biological Revolution, Veatch agreed with W. D. Ross that "to give special consideration to harms over benefits is to deviate from the simple utilitarianism of Mill and Moore." ${ }^{8}$ However true this may be of Moore, no one who has taken the trouble to read Mill could have writ ten such a statement! This is one of the main problems with today's deontological critics of Mill. Most of them seem never to have read Mill.

Mill's Principle of Utility contains a maximizing view only of what is ideally desirable, not of what is morally obligatory. Now our problem is, how do we get from the one to the other, from a maximizing view of what is desirable to a minimizing view of what is morally obligatory? What special considerations must be introduced before the Principle can function properly as the "foundation" of a minimizing theory of moral obligation?

According to Mill, there are at least two necessary conditions which must be taken into account in order to identify what he called "the domain of moral duty." 9 First of all, only those acts are morally obligatory which are so essential to the well being of other persons or sentient creatures that society is justified in requiring and enforcing them through the use of those negative reenforcers which Mill called the "sanctions" of morality. The most important of these sanctions were the pain-inducing motivators of adverse public opinion, 10 legal coercion and guilty conscience, especially the latter. ${ }^{11}$ Bringing these into play counted as "punishment" in Mill's very broad sense of the term. The costs of initiating, teaching and enforcing these sanctions have to be taken into account in determining which acts are to count as morally obligatory. Once these costs are counted, Mill was convinced that only a relatively few desirable acts can be classified as moral obligations, i.e. as acts that society justifiably could coercively require of its members. Other desirable acts fall into non-moral domains such as those of manners, aesthetic tastes, prudential well being or expediency, exalted heroism, and saintly self sacrifice. These can be positively encouraged and promoted, but the price of "punishing" persons for non-conformity in these areas is too high. There are many passages in which Mill developed his idea that correlation with justifiable sanctions, i.e. those worth the price, is a necessary condition for identifying moral obligations. In the following discussion, the class of desirable acts and even of moral virtues is far larger than the class of morally required acts 

of positive moral duty.

Utilitarian morality fully recognises the distinction bet ween the province of positive duty and that of virtue, but maintains that the standard and rule of both is the general interest. From the utilitarian point of view, the distinction between them is the following:-There are many acts, and a still greater number of forbearances, the perpetual practice of which by all is so necessary to the general well-being, that people must be held to it compulsorily, either by law, or by social pressure. These acts and forbearances constitute duty. Outside these bounds, there is the innumerable variety of modes in which the act $s$ of human beings are either a cause, or a hindrance, of good to their fellow-creatures, but in regard to which it is, on the whole, for the general interest that they should be left free; being merely encouraged, by praise and honour, to the performance of such beneficial actions as are not sufficiently stimulated by benefits flowing from them to the agent himself. This larger sphere is that of Merit or Virtue. ${ }^{12}$

Again, in writing of the idea of "moral obligation in general," Mill explained that:

We do not call anything wrong unless we mean to imply that a person ought to be punished in some way or other for doing it - if not by law, by the opinion of his fellow creatures; if not by opinion, by the reproaches of his own conscience. This seems the real turning point of the distinction between morality and simple expediency. It is a part of the notion of duty in every one of its forms that a person may rightfully be compelled to fulfill it. Duty is a thing which may be exacted from a person, as one exacts a debt. Unless we think that it may be exacted from him, we do not call it his duty. ${ }^{13}$

For Mill, a second necessary condition for the identification of morally right or wrong acts is that they should always be correlated with concrete rules. Mill's position on such rules is actually quite complex. $\mathrm{He}$ insisted that "secondary principles" are always involved in identifying morally obligatory acts, that in no case can we identify such acts through a direct application of the fundamental axiom of morality, much less the Principle of Utility itself. Mill claimed that "Whatever we adopt as the fundamental principle of morality, we require subordinate principles to apply it," 14 and that "There is no case of moral obligation in which some secondary principle is not involved." 15 In some cases, the rules involved are those already existing rules already recognized by society; society will exact its revenge for violating its rules whether they are good rules or not. In the real world, existing rules cannot be ignored or flaunted without peril. As a moral or social reformer, however, the utilitarian can propose and actively lobby for the adoption of $i d e a l$ rules which would better protect persons from harm and promote the minimal essentials of well being. ${ }^{16}$ Needless to say, in this realm of application, there is ample room for legitimate disagreement concerning the content of the ideal rules. It is as true in our day as it was in Mill's that "the received code of ethics is by no means of divine right; and that mankind have still much to learn as to the effects of actions on the general happiness." 17 
Secondary rules like "do not steal, except ..." or "do not kill, except ..." are vital to any working morality. They enable us to know what others can reasonably expect of us. ${ }^{18}$ They are readily available as probability guides when sudden decisions are called for that do not allow time for calculation. ${ }^{19} \mathrm{At}$ their best, they are based upon aeons of past experience concerning the general kinds of human acts that tend to result in harm to others. ${ }^{20}$

Ideal rules are justified when their benefits clearly exceed their costs, i.e. when the harm and suffering prevented by them clearly exceeds the harm and suffering caused by the supporting sanctions and by the societal effort which must be expended in getting the rules adopted and teaching and learning the rules. Thus they are grounded in the Principle of Utility, for, unlike the rules of prudence, it is "for the good of mankind that (we) be held accountable" 21 for obedience to such rules. Mill was greatly concerned that his moral theory be applicable in the real world, taking all the frailties of ordinary people into account. For this reason, he insisted that even ideal moral rules had to be relatively simple so that they could be easily taught and learned. ${ }^{22}$ This meant that although they could incorporate a limited list of explicit qualifications and exceptions, they could not incorporate an indefinitely lengthy list of them. Even the exceptions like stealing to prevent one's family from starving had to be justified on the ground that as a class they were less harmful to the essential well being of others than obedience to the unqualified rule itself would be. ${ }^{23}$

Since they cannot have all the legitimate exceptions written into them in a working morality, even ideal rules will come into conflict with one another at times. It is at this point that the Principle of Utility again comes into play, for conflicts of rules are to be decided in favor of that rule which least violates the Principle. As Mill acknowledged,

It is not the fault of any creed, but of the complicated nature of human affairs, that rules of conduct cannot be so framed as to require no exceptions ... There exists no moral system under which there do not arise unequivocal cases of conflicting obligation ... If utility is the ultimate source of moral obligations, utility may be invoked to decide bet ween them when their demands are incompatible .. . We must remember that only in these cases of conflict between secondary principles is it requisite that first principles should be appealed to. ${ }^{24}$

It is most important, however, that we carefully interpret the precise nat ure of Mill's appeal to the Principle of Utility in resolving conflicts of moral rules. Within the "province" of morality, there is no moral obligation to maximize goodness or to be benevolent in that sense. Thus, acting on the rule which maximizes positive benefits cannot be a morally enforcable resolution to such a conflict, though this interpretation is commonplace. The morally correct resolution to the problem of conflicting rules is rather the minimizing option, i.e. that we should act on that rule which involves the least infliction of harm, the prevention of the most harm, or the best provision of minimal essentials 
of well being. A minimizing moral utilitarianism can require no more than this. We must remember that Mill's position incorporates no moral rules designed to maximize happiness or well being and that such rules thus cannot be among those which come into conflict with one another within the province of morals. Most legitimate moral rules are negative rules which forbid the infliction of harm, though there are some additional rules which require positive acts calculated to prevent harm and to promote minimal well being. As he wrote in On Liberty,

I regard utility as the ultimate appeal on all ethical questions; but it must be utility in the largest sense, grounded on the permanent interests of man as a progressive being. Those interests, I contend, authorize the subjection of individual spontaneity to external control, only in respect to those actions of each, which concerns the interests of other people. If any one does an act hurtful to others, there is a prima facie case for punishing him, by law, or, where legal penalties are not safely applicable, by general disapprobation. There are also many positive acts for the benefit of others, which he may rightfully be compelled to perform; such as, to give evidence in a court of justice; to bear his fair share in the common defence, or in any other joint work necessary to the interest of the society of which he enjoys the protection; and to perform certain acts of individual beneficence, such as saving a fellow creature's life, or interposing to protect the defenceless against ill-usage, things which whenever it is obviously a man's duty to do, he may rightfully be made responsible to society for not doing. A person may cause evil to others not only by his actions but by his inaction, and in either case he is justly accountable to them for the injury. The latter case, it is true, requires a much more cautious exercise of compulsion than the former. To make any one answerable for doing evil to others, is the rule; to make him answerable for not preventing evil, is, comparatively speaking, the exception. Yet there are many cases clear enough and grave enough to justify that exception. ${ }^{25}$

As David Lyons has pointed out, we must be very careful not to interpret "positive acts for the benefit of others" in this passage to mean "acts for the positive benefit of others." 26 All of Mill's examples here deal with abstaining from or preventing harm. In his doctrine of rights, ${ }^{27}$ Mill extended the domain of moral obligations to cover acting to provide others with minimal essentials of well being, but none of this adds up to a moral obligation to maximize happiness or well being, however desirable that might otherwise be. Mill recognized no such socially enforcable obligation, either to oneself or to others. In explaining his utilitarianism to Thomas Carlyle in 1834, Mill wrote that "I have never, at least since I had any convictions of my own, belonged to the benevolentiary, soup-kitchen school." 28

In light of the foregoing considerations, it is evident that Professor Veatch's most elemental mistake is that of classifying John Stuart Mill as a maximizing act utilitarian who adopted what Veatch calls "the principle of benevolence" as his most basic moral principle.

\section{Part II: Veatch on Supererogation, Moralizing All of Life, and Promise Keeping}

Robert M. Veatch offers a number of specific criticisms of what he takes to be the utilitarian position common to Mill, Bentham and others 
in his $A$ Theory of Medical Ethics. I shall now turn to these. I will show that Mill's position does not succumb to any of these criticisms. Though he acknowledges that he has taken his specific criticisms from another author, ${ }^{29}$ Veatch has conveniently summarized five of his basic theoretical objections to utilitarianism as follows:

Utilitarians face the problem of choosing among various competing ways of producing the greatest net good. None of them squares with the obvious, if simplistic, psychology of egoism. Moreover, many of the utilitarianisms seem to lead to highly implausible, counterintuitive implications: that superhuman acts normally referred to as supererogatory are morally required provided they produce even slightly more good on balance than alternative actions; that even trivial choices among actions are elevated to moral obligations if they produce even slightly greater benefit (the choice among breakfast cereals, for example): that the only reason to keep promises is because keeping them produces or tends to produce the best consequences; that punishment should be meted out on the basis of the consequences rather than on the basis of who deserves the punishment; and that the distribution of the benefits and harms counts for nothing in the concept of justice except as it has an impact on total aggregate consequences. ${ }^{30}$

Now we shall consider these five objections in some detail.

(1) Objection 1 is that utilitarianism cannot allow a place for supererogation, i.e., for the recognition of desirable actions which clearly go beyond the call of moral duty. Veatch explained that the Principle of Utility

is a principle that seems to require perfection in every moment in order for one to lead a moral life. But most people feel that they need not always conduct themselves in a way that will produce more good results on balance that other course. While producing good is often considered relevant to deciding what is morally required, there are times when doing what will produce the most good is supererogatory, that is, morally commendable but not necessarily morally required. ${ }^{31}$

Those who take the trouble actually to read Mill himself will find that he too maintained that many saintly and heroic acts fall outside the sphere of the morally required but inside the sphere of the morally commendable. Mill insisted that the class of morally virtuous acts and dispositions is far broader than the class of morally obligatory acts and dispositions. Furthermore, for Mill, the Principle of Utility did not require that supererogatory acts be morally obligatory. Instead, the Principle excluded such acts from the domain of moral obligation precisely because the cost of coercing people to be saints and heroes at all times is far too great. The Principle allows us to identify such acts as highly desirable, as deeds to be positively encouraged, but not as deeds to be enforced by negative moral sanctions or identified by compulsory moral rules. In his 1865 essay on "The Later Speculations of $\mathbf{M}$. Comte," Mill accused Auguste Comte of being "a morality-intoxicated man. Every Question with him is one of morality, and no motive but that of morality is permitted." 32 Mill insisted that Comte's position:

makes the same ethical mistake as the theory of Calvinism, that every act in life should be done for the glory of God, and that whatever is not a duty is a sin. It does not perceive that 
between the region of duty and that of sin there is an intermediate space, the region of positive worthiness. It is not good that persons should be bound, by other people's opinion, to do everything that they would deserve praise for doing. There is a standard of alt ruism to which all should be required to come up, and a degree beyond it which is not obligatory, but meritorious. It is incumbent on every one to restrain the pursuit of his personal objects within the limits consistent with the essential interests of others. What those limits are, it is the province of ethical science to determine; and to keep all individuals and aggregations of individuals within them, is the proper office of punishment and of moral blame. If in addition to fulfilling this obligation, persons make the good of others a direct object of disinterested exertions, postponing or sacrificing to it even innocent personal indulgences, they deserve gratitude and honor, and are fit objects of moral praise. So long as they are in no way compelled to this conduct by any external pressure, there cannot be too much of it; but a necessary condition is its spontaneity; since the notion of happiness for all, procured by the self-sacrifice of each, if the abnegation is really felt to be a sacrifice, is a contradiction. Such spontaneity by no means excludes sympathetic encouragement; but the encouragement should take the form of making self-devotion pleasant, not that of making everything else painful. The object should be to stimulate services to humanity by their natural rewards; not to render the pursuit of our own good in any other manner impossible, by visiting it with the reproaches of others and of our own conscience. ${ }^{33}$

As a rule of conduct, to be enforced by moral sanctions, we think no more should be attempted than to prevent people from doing harm to others, or omitting to do such good as they have undertaken. Demanding no more than this, society, in any tolerable circumstances, obtains much more; for the natural activity of human nature, shut out from all noxious directions, will expand it self in useful ones. This is our conception of the moral rule prescribed by the religion of Humanity. But above this standard there is an unlimited range of moral worth, up to the most exalted heroism, which should be fostered by every positive encouragement, though not converted into an obligation. It is as much a part of our scheme as of $M$. Comte's, that the direct cultivation of altruism, and the subordination of egoism to it, far beyond the point of absolute moral duty, should be one of the chief aims of education, both individual and collective ... Nor can any pains taken be too great, to form the habit, and develop the desire, of being useful to others and to the world, by the practice, independently of reward and of every personal consideration, of positive virtue beyond the bounds of prescribed duty. ${ }^{34}$

In recognizing a realm of positive worthiness, moral worth, moral praise, positive virtues, habits, desires, etc. lying "beyond the bounds of prescribed duty," Mill perpetuated an ambiguity in the concept of the "moral" which exists in ordinary discourse. There is an apparent incoherence between our regarding and praising the saint and the hero as an exceptionally moral person precisely because their deeds exceed morality, i.e. go beyond the call of duty. This merely means that our concept of moral virtue is broader than our concept of moral obligation. As Mill put it, "Utilitarian morality fully recognizes the distinction between the province of positive duty and that of virtue, but maintains that the standard and rule of both is the general interest." 35 Clearly, Mill's utilitarianism does not yield to Veatch's first objection. It definitely can and does make a place for supererogation; it will unquestionably allow us to distinguish between what is "morally commendable but not necessarily morally required." 36 A duty to "Do good" is not equivalent to a duty to "Maximize good." 
(2) Veatch's second objection to utilitarianism is that it moralizes the whole of life, that "even trivial choices among actions are elevated to moral obligations if they produce even slightly greater benefit (the choice among breakfast cereals, for example)." 37 This objection, like the preceding, is predicated upon the unwarranted assumption that Mill's was a maximizing utilitarianism. We have seen that Mill castigated Comte for being a morality intoxicated man for whom every question was a moral question. We have already identified a broad domain of "positive worthiness," i.e. of desirable heroic and saintly behaviors and virtues that for Mill were not "elevated to moral obligations." It should be clear enough by now that in a minimizing utilitarianism there are many non-trivial as well as trivial choices which cannot be classified as moral duties because the price of societal coercion is these areas would be too high, because the social adoption and enforcement of action-guiding rules requiring such behaviors would be counter productive. It is usually best for mankind that liberty be the rule rather than moral constaint.

The main thrust of Veatch's second objection seems to focus on self-interested acts. The example of "the choice among breakfast cereals" seems to illustrate the charge that utilitarianism elevates even trivial prudential choices to the domain of moral obligations. In response, we must point out that Mill's utilitarianism clearly distinguished between prudential obligations and moral obligations. The Principle of Utility is just as much the basic axiom of Prudence as it is of Morals. With respect to matters of self-interest, it is desirable that we optimize our own happiness, but this by no means entails that acting to do so is morally obligatory, i.e. that such acts are ideally correlated with behavioral rules that should be supported by social negative reenforcers. On the contrary, Mill took the rather extreme position that as rational adults we have no moral obligations to ourselves whatsoever. Our natural self interest and personal self knowled ge serve well enough to motivate us to pursue our own happiness or well being without being coerced by society to do so. Prudence is unquestionably something to be positively encouraged but not something to be negatively required by others. Again, it is the Principle of Utility which requires that we not moralize prudence, even in matters of utmost importance, not to mention trivialities. It is best that some areas of life be left to the individual and be free from societal coercion, i.e. best that we not moralize the whole of life, but that liberty be the rule. As Mill explained in On Liberty, in matters of self interest it is not "for the good of mankind that (we) be held accountable to them." 38 In more detail,

The only freedom which deserves the name, is that of pursuing our own good in our own way, so long as we do not attempt to deprive others of theirs, or impede their efforts to obtain it. Each is the proper guardian of his own health, whether bodily, or mental and spiritual. Mankind are greater gainers by suffering each other to live as seems good to themselves, than by compelling each to live as seems good to the rest. ${ }^{39}$ 
I am the last person to undervalue the self-regarding virtues; they are only second in importance, if even second, to the social. It is equally the business of education to cultivate both. But even education works by conviction and persuasion as well as by compulsion, and it is by the former only that, when the period of education is past, the self-regarding virtues should be inculcated. Human beings owe to each other help to distinguish the better from the worse, and encouragement to choose the former and avoid the latter. They should be forever stimulating each other to increased exercise of their higher faculties, and increased direction of their feelings and aims towards wise instead of foolish, elevating instead of degrading, objects and contemplations. ${ }^{40}$

In the conduct of human beings towards one another, it is necessary that general rules should for the most part be observed, in order that people may know what they have to expect; but in each person's own concerns, his individual spontaneity is entitled to free exercise. Considerations to aid his judgment, exhortations to strengthen his will, may be offered to him. even obtruded on him, by others; but he, himself, is the final judge. All errors which he is likely to commit against advice and warning, a re far out weighed by the evil of allowing others to constrain him to what they deem his good. ${ }^{41}$

Again, it is clear that although Mill's utilitarianism did recognize the importance of prudence and did allow for the positive encouragement of such by others, he nevertheless did not elevate obligations of self interest to the status of moral obligations, i.e. obligations to be coercively constrained by others. Thus, Mill's position is clearly not vulnerable to Veatch's second objection.

(3) Veatch's third objection is that utilitarianism accounts inadequately for the duty of promise keeping because "the only reason to keep promises is because keeping them produces or tends to produce the best consequences." 42 It is tempting to respond with the question: Well, what other reason is there? Of course, there is an answer, one which was popularized by Sir David Ross, who wrote that

When a plain man fulfills a promise because he thinks he ought to do so, it seems clear that he does so with no thought of its total consequences, still less with any opinion that these are likely to be the best possible. He thinks in fact much more of the past than of the future. What makes him think it right to act in a certain way is the fact that he has promised to do so- that and, usually, nothing more. ${ }^{43}$

Although Veatch does not explain his objection respecting promise keeping, his point seems to be that the proper reason for keeping promises is that they have been made, not that they are likely to have the best consequences. Since utilitarianism looks entirely at future consequences, it cannot account for such a "past-looking" reason, as innumerable critics since Ross have echoed.

There are at least three important elements in a proper reply to this sort of criticism from the point of view of Mill's minimizing utilitarianism. Most importantly, any utilitarian who is not a sheer idiot will realize that many things which we did in the past make a difference in the present and the future. Mill firmly believed that as utilitarians we can and should keep promises because we made them in the past, though this is never the whole story. In deciding whether to keep a promise, the utilitarian never finds himself in the situation of deciding 
which course of action would be best just as if a promise had never been made. The reason for this is that past promises have the significant effect of raising the present and future expectations of the promisee and others who know the promise was made. Thus, the future consequences of performing an act that breaks a promise are never the same as performing the same act in the absence of having made that promise in the past.

The second thing that needs to be said about Veatch's objection concerning promise keeping is that Mill did not justify promise keeping on the grounds that doing so "produces or tends to produce the best consequences," though no doubt much has been and could be said in favor of this maximizing position. ${ }^{44}$ Mill's justification was tied not to a moral duty of positive benvolence but rather to nonmaleficence. Mill thought promise breaking to be morally wrong because of its "connection with hurt or injury," as he explained:

The important rank, among human evils and wrongs, of the disappointment of expectation is shown in the fact that it constitutes the principle criminality of two such highly immoral acts as a breach of friendship and a breach of promise. Few hurts which human beings can sustain are greater, and none wound more, than when that on which they habitually and with full assurance relied fails them in the hour of need; and few wrongs are greater tha $n$ this mere withholding of good; none excite more sentiment, either in the person suffering or in a sympathizing spectator. ${ }^{45}$

Although Mill recognized no general moral obligation to maximize goodness, he did recognize a moral obligation to do as much good as we have contracted, promised or "undertaken" to do. It is appropriate to use moral sanctions to prevent people from "omitting to do such good as they have undertaken." 46 Mill recognized the negative utility of even this obligation, again justifying its enforcement on the grounds of its connection with institutionalized practices and disappointed expectations:

When we either expressiy or tacitly undertake to do more, we are bound to keep our promise. And inasmuch as every one, who avails himself of the advantages of society, leads others to expect from him all such positive good offices and disinterested services as the moral improvement attained by mankind has rendered customary, he deserves moral blame if, without just cause, he disappoints that expectation. ${ }^{4}$ ?

The third important element in a proper utilitarian reply to Veatch on promise keeping may be introduced in relation to the problem concerning promises to promote positive well being that are made in secret, especially where the promisee has died and it is certain that no one else knows that the promise has been made. Should the arctic explorer keep his promise to educate his compatriot's children made when the compatriot gave him all his rations so that he alone could make it back to civilization? Should the doctor keep death bed promises to do good that he alone knows about? An affirmative utilitarian answer is based upon the fact that promise keeping is an institutionalized practice. 
As we have seen, Mill recognized no general obligation to promote positive well being. Yet, he did acknowledge a special obligation to do good once we have "undertaken" or promised to do so. Even institutionalized practices like promise keeping may have legitimate exceptions written into them, however, a fact that Rawls failed to take into account. Would Mill have thought "except when no other living person knows about it" to be a legitimate exception to the rule of keeping promises to do good? Well, in fact he did not recognize this exception, perhaps only because he did not discuss it. However, there are perfectly sound utilitarian grounds for not institutionalizing this exception. First of all, the very practice of making secret promises would be eliminated by such an exception. Yet, there are situations in which we would all want others to make secret promises to us that could be fulfilled only after our death. Such an exception would simply crush in advance our hopes for "such positive good offices and disinterested services." It is just as harmful to crush hopes as to disappoint expectations.

For Mill, moral right and wrong are identifiable only in relation to moral rules that are a part of a general social practice that includes both the inculcation and the coercive enforcement of desirable social rules. If the rule that "We should keep our secret promises to do good after the death of the promisee" is justifiable as a way of avoiding crushed hopes, this desirable institutional practice must be supported both by public opinion and a properly trained conscience for they too are essential parts of the practice. If Veatch's or anyone else's conscience hurts at the very thought of violating a secret promise, that is just as it should be on utilitarian grounds. Without some such sanction to help insure compliance this desirable institutional practice would not exist.

The duty of promise keeping is very important to Veatch, being one of the five deontological moral principles which he believes to be justified without appeal to consequences. ${ }^{48}$ It lies at the heart of the idea of a contractual relationship between physician and patient, and it is involved in the medical profession's promise of confidentiality to clients. ${ }^{49} \mathrm{We}$ have seen that the social practice of promise keeping can be justified on utilitarian grounds which do take adequate account of the fact that in the past a promise was made and which accords with a minimizing utilitarian obligation to prevent harm rather than a benevolent duty to optimize goodness. Mill's utilitarianism has no difficulty in providing an adequate rationale for medical contracts and confidentiality commitments.

There is one troublesome feature of Veatch's deontological principle of promise keeping which is worth mentioning while on the subject, namely that one can read carefully through his whole book and not know exactly what it is. He never states it, just as he never states any of his five deontological principles, so we cannot look at it to determine whether he writes any legitimate exceptions into it or not. In one 
discussion, he gives us a choice between opting "for the principle of promise keeping without exception" or "for the principle that promises should be kept unless it is beneficial (really beneficial, including long term consequences) to break the promise," 50 his general antiutilitarianism creates the presumption that he finally favors the first option. On the other hand, he recognizes at least one possible conflict between justice and promise keeping in which justice should prevail. ${ }^{51}$ Thus he recognizes an exception to a principle that has no exception! Telling us that when his deontological principles conflict, "We should opt for the course that produces the lesser violation of the nonconsequentialist principles on balance" 52 does not help very much here since he does not tell us how to recognize such lesser violations. Mill's moral axiom would help here. It would be a considerable improvement on relying on Veatch's attempts to balance deontological stringencies by intuition. It would generate exceptions to promise keeping that are openly acknowledged and justified and which are based on harm to people rather than on harm to abstract principles: We should not keep our promises when, all things considered, it seems likely that keeping them would result in even greater harm to others and an even greater violation of their rights to the minimal essentials of any sort of well being whatsoever. None of these minimizing obligations involve moral obligations to produce the best consequences, only to prevent the worst and provide the minimum.

\section{Part III: Veatch on Penal and Distributive Justice}

(4) Veatch's two final objections to utilitarianism both pertain to issues of justice. First there is the charge that utilitarianism generates the wrong results with respect to penal justice, then with respect to distributive justice. The difficulty with respect to penal justice, as Veatch states it, is that utilitarianism implies "that punishment should be meted out on the basis of the consequences rather than on the basis of who deserves the punishment." 53 This is also a commonplace objection, though Veatch does not elaborate upon it. The point seems to be that utilitarianism is committed to punishing innocent persons if the greatest good or happiness of the greatest number could be thereby promoted. There are a number of things wrong with this objection, however, especially as applied to J. S. Mill.

The first and most obvious response is that although there may be some very simplistic versions of utilitarianism which would countenance punishing the innocent for the good of the greatest number, this objection is totally irrelevant to Mill's minimizing utilitarianism. There is no moral obligation to maximize goodness, only to minimize harm and provide minimally essential goods, in Mill's theory of moral obligation. Thus there is no moral obligation to do anything, much less punish the innocent, merely because the good would be maximized thereby. It must be admitted, however, that there is an initial 
presumption that even a minimizing utilitarianism is committed to punishing the innocent if thereby even greater harm could be prevented. It is this presumption which needs careful scrutiny.

The most obvious reason why minimizing utilitarianism is not committed to punishing the innocent for the greater good of others is purely conceptual in nature, namely that this is simply not what we mean by "punishment." Even John Rawls, a severe critic of utilitarianism, realized that utilitarians have a quick and easy conceptual escape from this difficulty. He indicated that "utilitarians agree that punishment is to be inflicted only for the violation of the law. They regard this much as understood from the concept of punishment itself." 54 Mill clearly thought that the institution of punishment was justified partly because it "restores the mind" of the offender to a "normal preponderance of the love of right," but primarily as a way of protecting "the just rights of others against unjust aggression by the offender." "ss He logically linked the concept of punishment to the notion of offence, i.e. of "wrong doing," "guilt," or "wrong conduct." 56 Its future-looking purposes of correcting and deterring offenders cannot be fulfilled for logical reasons unless there are offenders. We cannot correct someone who has not made a mistake or deter someone who is not likely to make a mistake. Since punishment is by definition the infliction of harm by a proper authority upon a person who has violated the rules, and since an innocent person is by definition one who has not violated the rules, the very idea of "punishing the innocent" is thus logically self-contradictory. Veatch's commonplace objection to utilitarianism is itself unintelligible.

Of course, as Rawls indicated, a subtle problem remains for utilitarianism even if we acknowledge that the very idea of "punishment the innocent" is logically incoherent: "The real question, however, is whether the utilitarian, in justifying punishment, hasn't used arguments which commit him to accepting the infliction of suffering on innocent persons if it is for the good of society." 57 Such a practice would not be punishment, but we might call it "telishment," Rawls suggested. ${ }^{58}$ Yet, upon examination, Rawls concluded that even a maximizing utilitarian would not want to pay the price of establishing and socially enforcing such a practice, that "If one pictures how such an institution would actually work, the enormous risks involved in it, it seems clear that it would serve no useful purpose. A utilitarian justification for this institution is most unlikely." 99

We must remember that for Mill an act is morally obligatory only if it is authorized by a moral rule, i.e. by what Rawls would call a "practice." Even a maximizing utilitarian would not want to adopt a rule which says that "We should inflict harm on innocent persons if greater good for others would result." The minimizing counterpart, however, would be that "if and only if nothing but harm will come of it no matter what we do, we should inflict harm on persons (whether innocent or not) only 
if greater harm for others may thereby be prevented." Put into the language of rights, "we should violate the rights of individual persons only where this is necessary to avoid an even greater violation of the rights of others, who are also individual persons." We should call this "minishment" to distinguish it from both punishment and telishment. This is just another way of presenting the "lesser of two evils" principle. It is precisely on this principle of minishment and not on any maximizing principle, that Jeremy Bentham actually justified the institution of punishment, writing that "all punishment is mischief: all punishment in itself is evil. Upon the principle of utility, if it ought at all to be admitted, it ought only to be admitted in as far as it promises to exclude some greater evil." 60 Whatever our moral intuitions may be with respect to this minishment rule of harm prevention, they should be evaluated quite independently of any rule which enjoins harming to maximize positive good. Contrary to Veatch's suggestion, neither Bentham nor Mill believed in punishing or otherwise harming persons in order to maximize good consequences, but they would have supported the societal adoption of rules and/or exceptions to rules, which allow individuals to be harmed if and only if, all things considered, even greater harm to and violation of the rights of others is likely thereby to be avoided. Mill's examples best expressed this idea of minishment when he wrote that "particular cases may occur in which some other social duty is so important as to overrule any one of the general maxims of justice. Thus to save a life it may not only be allowable, but a duty, to steal or take by force the necessary food or medicine, or to kidnap and compel to officiate the only qualified medical practitioner." 61

Though his instances of harm may not go quite far enough, even Robert Veatch thinks that violations of medical confidentiality are justified on the grounds of harm prevention, writing that physicians "should pledge confidentiality except when there is a clearly identified, direct, and immediate threat to life or grave bodily harm to another." 62 Veatch's own solution to the problem of exceptions to the rule of confidentiality is thus throughly utilitarian!

(5) Veatch's final objection, the one with respect to distributive justice, is "that the distribution of the benefits and harms counts for nothing in the concept of justice except as it has an impact on total aggregate consequences." 63 "Having an impact" here means "maximizes," for Veatch has just explained on the preceding page that the real difficulty with respect to distributive justice is that utilitarianism "justifies too much. By itself, it justifies any scheme that produces the greatest net aggregate benefit." ${ }^{4}$ Veatch conceded that the principle of marginal utility would tend heavily to equalize the distribution of benefits in a utilitarian social order because

it is usually the case that people who are in great need will benefit more from a fixed a mount of resources than those who are relatively well off. Usually, marginal utility from 
a given amount of a resource decreases as the amount of need decreases. In aggregating benefits, those effects will be correctly taken into account. ${ }^{65}$

Nevertheless, a grave difficulty remains for maximizing utilitarianism. As Veatch sees it, "it justifies too much," i.e.

it would justify the Nazi experiments if only the Nazis were clever enough to design an experiment that would produce great good for the masses while harming a small number of people in such a way that the aggregate net good was enhanced. If enough people receive the benefits, it is plausible that even enormous harms to a small number will be outweighed by the aggregate benefit to the masses. ${ }^{60}$

Veatch expressly intends that this objection should apply to Mill, for in the same paragraph he wrote that "There is, according to Mill and his followers, no means of resolution of conflicts over distribution except the utilitarian, the one that compares aggregate impacts of alternatives." 67 Now it is true that Mill believed that the Principle of Utility should be appealed to directly, both when moral rules conflict and when exceptions to moral rules need to be made. As we have seen, however, a moral application of the Principle is not a maximizing application. What a moral appeal to the Principle tells us is that we should act on that rule, or make those exceptions, which minimize harm, including those harms which result when the basic rights of individuals are violated. As Mill himself explained,

I account the justice which is grounded on utility to be the chief part, and incomparably the most sacred and binding part, of all morality. Justice is a name for certain classes or moral rules which concern the essentials of human well-being more nearly, and are therefore of more absolute obligation, than any other rules for the guidance of life; and the notion which we have found to be of the essence of the idea of justice-that of a right residing in an individual-implies and testifies to this more binding obligation.

The moral rules which forbid mankind to hurt one another (in which we must never forget to include wrongful interference with each other's freedom) are more vital to human well-being than any maxims, however important, which only point out the best mode of managing some department of human affairs. ${ }^{68}$

Harmful acts against some individuals calculated to increase positive good for others, which Veatch believes to be required by utilitarian morality, turn out to be the very kinds of act that utilitarian morality forbids! Veatch and other deontologists who think that deontology has some kind of monopoly on human rights and that utilitarianism cannot make a place for them have simply never taken the trouble to read and understand the concluding chapter of Mill's Utilitarianism.

There are, of course, many other difficulties with respect to distributive justice, though the specific difficulty raised by Veatch is easy enough to resolve. Worth mentioning in conclusion is the problem that in our society and in the writings of our philosophers there is no such thing as justice, there are only justices. By this I mean that anyone who pays careful attention to how the term justice is defined by philosophers and plain men will discover that there are available many 
often incompatible concepts of distributive justice and correspondingly many often incompatible intuitions of justice. We must choose among them somehow. Mill realized this and identified more than a half dozen concepts of justice in the concluding chapter of his Utilitarianism. Recently, after examining the gross incompatibilities between justiceaccording-to-Rawls and justice-according-to-Nozick, Alasdair MacIntyre concluded that "we have all too many disparate and rival moral concepts, in this case rival and disparate concepts of justice, and that the moral resources of the culture allow us no way of settling the issue between them rationally." 69 For anyone who has read Mill, the recognition that we have many rival and disparate concepts of justice is nothing new at all. To those who complained that utility was "an uncertain standard" but that justice was not, Mill replied that

there is as much difference of opinion, and as much discussion, about what is just as about what is useful to society. Not only have different nations and individuals different notions of justice, but in the mind of one and the same individual, justice is not some one rule, principle, or maxim, but many which do not always coincide in their dictates. ${ }^{70}$

Veatch himself acknowledged and discussed the rivalry between Rawlsian maximin justice and the more egalitarian theory of justice which he favors. ${ }^{71}$ He apparently thinks that we can choose between rival concepts of justice by consulting the deontological intuitions of rational persons, but this does not work at all for me. I can think of at least twelve distinct and often incompatible concepts of social or distributive justice; and when I consult my intuitions, even in my most rational moments, I find that I have intuitions of justice corresponding to almost every last one of them! I suspect that any honest person will have the same difficulty! Consider the following definitions which various philosophers have championed. Social or distributive justice or fairness consists in:

1. Finding and staying in one's proper place in the social order. (Plato)

2. Contracting not to harm others in exchange for not being harmed by them. (Epicurus)

3. Distributing benefits to those who deserve to get them. (Aristotle)

4. Distributing liberty and other primary goods so as to optimize benefits for the least advantaged, with no consideration of desert or merit. (John Rawls)

5. Distributing good things only to those who are entitled to have them through having obtained them by free contracts, gifts or exchanges, in an overall just social system. (Robert Nozick)

6. Distributing benefits so as to maximize the greatest happiness of the greatest number. (Maximizing utilitarianism)

7. Distributing benefits so that each gives according to his ability and gets according to his need. (Karl Marx) 
8. Upholding the institution of private property. (David Hume)

9. Treating similar cases in similar ways. (Henry Sidgwick)

10. Distributing benefits so as to equalize net welfare for all. (Egalitarian theorists)

I1. Giving all persons an equal opportunity to obtain equal benefits. (Robert M. Veatch)

12. Equal societal protection from harm and provision of minimal essential goods for all. (J. S. Mill)

What is needed, obviously, is some way of choosing between such rival concepts of justice and the intuitions with which they correlate. I shall not confront the issue, raised by MacIntyre, whether reason can resolve ultimate disagreements in ethics. I will conclude by pointing out that disagreements concerning concepts and intuitions of justice need not be regarded as ultimate disagreements, for a more basic principle of value can be introduced to resolve disagreements about concepts of justice. Mill asked "Who shall decide between these appeals to conflicting principles of justice?" and answered, not who, but how: "Social utility alone can decide the preference." 22 The view of justice which Mill thought to be most in accord with a moral application of the Principle of Utility was neither a maximin theory which says distribute the largest possible number of good things to the least advantaged nor an egalitarian theory which says distribute an equal number of good things to everyone. The only socially enforcable theory of justice worth the price is a minishment theory which says distribute to everyone equally according to their capacity to use them those minimal essentials of well being which we identify as rights and judge to be so fundamental to well being that they are worth the price of strong measures of coercive societal protection on every particular occasion.

With this I rest my case against Veatch and my defense of Mill against his objections. My minimal verdict is that persons searching for an adequate theory of ethics upon which to ground the particularities of medical ethics should not reject utilitarianism, at least not for any of the reasons Veatch has given. ${ }^{*}$

\footnotetext{
* Writing of this article was supported by a Summer Research Grant from the University of Tennessee. It was given as the Presidential Address to the 1985 meeting of the Southern Society for Philosophy and Psychology in New Orleans.

\section{NOTES}

' Robert M. Veatch, A Theory of Medical Ethics, New York, Basic Books, Inc., 198I, pp. $170,297$.

2 Ibid., pp. 146, 297.

${ }^{3} \mathrm{Ibid}$., p. 146. For other formulations of what Veatch takes to be the principle of utility or benevolence, see pp. 155, 170, 297.

${ }^{4}$ John Stuart Mill, Utilitarianism, Ch. Il, Footnote $\# 2$.
} 
${ }^{5}$ See for example: D. G. Brown, "What is Mill's Principle of Utility?" Canadian Journal of Philosophy, Vol. III, Sept. 1973, pp. 1-12; David Lyons, "Human Rights and the General Welfare," Philosophy \& Public Affairs, Vol. 6, Winter 1977, pp. 113-129; David Lyons, "Benevolence and Justice in Mill," in Harlan B. Miller and William H. Williams, eds., The Limits of Utilitarianism, Minneapolis, University of Minnesota Press, 1982, pp. 42-70; Gerald F. Gaus, "Mill's Theory of Moral Rules," Australasian Journal of Philosophy, Vol. 58, Sept. 1980, pp. 265-279.

- John Stuart Mill, A System of Logic, Bk. Vl., Ch. XIl.

7 John Stuart Mill, On Liberty. Ch. 1, par. 9.

${ }^{8}$ Robert M. Veatch, Death, Dying, and the Biological Revolution, New Haven, Yale University Press, 1976, p. 208.

9 John Stuart Mill, "The Later Speculations of M. Comte," 1865, par. 12.

${ }^{10}$ For a detailed account of what Mill meant by the sanction of public opinion, see his "Utility of Religion," par. 16.

11 Mill, Utilitarianism, Ch. III.

12 John Stuart Mill, "Thornton on Labor and its Claims," 1869, Part II, par. 9.

${ }_{13}$ Mill, Utilitarianism, Ch. V, par. 14. This whole paragraph is most important!

14 Ibid., Ch. II, par. 24.

is lbid., par. 26.

10 Ibid., par. 24.

17 Ibid.

${ }_{18}$ Mill, On Liberty, Ch. 4, par. 4.

${ }^{19}$ Mill, Utilitarianism, Ch. II., par. 24.

${ }^{20} \mathrm{lbid}$.

21 Mill, On Liberty, Ch. 4, par. 6.

22 Mill, A System of Logic, Bk. VI, Ch. XII, Sect. 3, par. 2. .

${ }^{23}$ Mill, Utilitarianism, Ch. V., par. 37.

${ }^{24}$ Ibid., Ch. II, par. 25.

${ }^{25}$ Mill, On Liberty, Ch. I, par. 11.

${ }^{26}$ David Lyons, "Benevolence and Justice in Mill," p. 50.

${ }^{27}$ Mill, Utilitarianism, Ch. V.

28 John Stuart Mill, letter "To Thomas Carlyle," Jan. 12, 1834, par. 3.

29 Veatch says he drew his criticisms from Fred Feldman's Introductory Ethics. See Veatch, $A$ Theory of Medical Ethics, p. 352, Footnote $\$ 15$.

${ }^{30}$ Ibid., pp. 260-61.

${ }^{31}$ Ibid., p. 146.

${ }^{32}$ Mill, "The Later Speculations of M. Comte," par. 9.

3. Ibid., par. 12.

34 Ibid., par. 14.

${ }^{35}$ Mill, "Thornton on Labor and its Claims," Part II, par. 9.

${ }^{36}$ Veatch, $A$ Theory of Medical Ethics, p. 146.

${ }^{37}$ Ibid., p. 261.

${ }^{38}$ Mill, On Liberty, Ch. 4, par. 6.

${ }^{39}$ Ibid., Ch. 1, par. 13.

${ }^{40} \mathrm{Ibid}$., Ch. 4, par. 4.

${ }^{41} \mathrm{Ibid}$.

${ }^{42}$ Veatch, $A$ Theory of Medical Ethics, p. 261.

${ }^{43}$ W. D. Ross, The Right and the Good, Oxford, The Clarendon Press, 1930, p. 17. See also pp. $21,37$.

44 Veatch himself says much in favor of this view, A Theory of Medical Ethics, p. 181.

${ }^{45}$ Mill, Utilitarianism, Ch. V, par. 34. See also par. 8.

${ }^{46}$ Mill, "The Later Speculations of M. Comte," par. 14.

${ }^{47}$ Ibid., par. 12.

48 Veatch, $A$ Theory of Medical Ethics, pp. 177-184.

${ }^{49}$ Ibid., pp. 177-189.

so Ibid., p. 181 . 
s1 Jbid., pp. 286-87.

52 Ibid., p. 304.

${ }_{53}^{3}$ Ibid., p. 261.

54 John Rawls, "Two Concepts of Rules," in Michael D. Bayles, ed., Contemporary Utilitarianism, Garden City, Anchor Books, 1968, p. 64.

ss John Stuart Mill, An Examination of Sir William Hamilton's Philosophy, Ch. 26, par. 26.

so Ibid., pars. 24-26.

${ }^{57}$ Rawls, "Two Concepts of Rules," p. 67.

58 Ibid., p. 70.

59 Ibid., p. 71

${ }^{\circ 0}$ Jeremy Bentham, An Introduction to the Principles of Morals and Legislation, $\mathrm{Ch}$.

13, par. 2.

61 Mill, Utilitarianism, Ch. V., par. 37.

62 Veatch, $A$ Theory of Medical Ethics, p. 187.

${ }^{63} \mathrm{Ibid}$., p. 261.

${ }^{64} \mathrm{Ibid}$., p. 260.

os Ibid, p. 269.

ob lbid., p. 260.

${ }^{67}$ Ibid.

${ }_{68}^{6}$ Mill, Utilitarianism, Ch. V., pars. 32, 33.

${ }^{69}$ Alasdair Maclntyre, After Virtue, Notre Dame, University of Notre Dame Press, 1981, p. 235.

70 Mill, Uilitarianism, Ch. V, par. 27.

71 Veatch, A Theory of Medical Ethics, pp. 261-269.

12 Mill, Utilitarianism, Ch. V, par. 30. 